\title{
TIPE KOMUNITAS HUTAN LAHAN KERING DI HUTAN LINDUNG SENTAJO, KABUPATEN KUANTAN SINGINGI, RIAU
}

\author{
Community Types of Dryland Forest Within The Sentajo Protected Forest, Kuantan \\ Singingi Regency, Riau Province \\ Pebriandi $^{1}$, Omo Rusdiana ${ }^{1}$ dan Muhammad Buce Saleh ${ }^{2}$ \\ ${ }^{1}$ Departemen Silvikultur, Fakultas Kehutanan IPB \\ ${ }^{2}$ Departemen Manajemen Hutan, Fakultas Kehutanan IPB
}

\begin{abstract}
Sentajo Protected Forest located in Kuantan Singingi Regency, Riau Province. There is no information about vegetation diversity in this location. Therefore this study was conducted. This study aimed to determine the diversity of vegetation, structure, and composition of each community in Sentajo Protected Forest. The study was conducted in AprilSeptember 2016. A sampling design was determined using systematic sampling with random start. The sampling intensity used was 5\%. The parameters measured in this study were the importance value index, similarity index between communities, species diversity index, evenness index, dominance index, regeneration, as well as horizontal and vertical structures. Based on the type of soil, elevation, and slope, 6 communities were grouped from the dense coverage area (forested). The results showed that the Sentajo Protected Forest had 424 flora consisted of 254 species, and 102 families. Sentajo Protected Forest had similarity index between $18-64 \%$, species diversity index of $2.62-4.15$, evenness index of 0.59 - 0.86, dominance index of 0.02 - 0.08. The larger the diameter of the tree, the smaller the number of individuals. The stratification of the canopy had 5 layers of canopy. Sentajo Protected Forest regeneration was relatively good as the number of seedlings $>$ saplings $>$ mature trees.
\end{abstract}

Key words: community, composition and structure, diversity, Sentajo Protected Forest.

\section{PENDAHULUAN}

Hutan dapat dipandang sebagai suatu ekosistem berdasarkan kelengkapan komponennya. Hutan mengandung komunitas flora dan fauna, baik tingkat tinggi maupun tingkat rendah serta lingkungan abiotik yang khas, ketiganya berinteraksi sangat erat sebagai suatu sistem ekologi. Diantara komponen-komponen penyusun hutan, pohon merupakan komponen penopang utama pada ekosistem hutan. Informasi tentang komponen penyusun ekosistem hutan dapat dilakukan dengan kegiatan analisis vegetasi. Analisis vegetasi merupakan suatu cara untuk mempelajari susunan dan atau komposisi vegetasi dalam suatu komunitas tumbuhan berdasarkan struktur vegetasi penyusunnya (Junaedi 2008).

Analisis vegetasi dapat dilakukan dengan berbagai metode. Meskipun demikian, hasil akhir yang diharapkan dari setiap analisis vegetasi adalah tersedianya informasi kuantitatif tentang struktur dan komposisi komunitas tumbuhan. Struktur dan komposisi hutan akan membentuk komunitas-komunitas yang ditentukan oleh faktor lingkungan, seperti tanah, kelerengan, dan elevasi. Penelitian untuk mempelajari potensi hutan, keanekaragaman, dan komposisi vegetasi dalam suatu komunitas hutan telah dilakukan pada berbagai ekosistem hutan. Misalnya Mukhlisin et al. (2013); Ghufrona et al. (2015) pada kawasan hutan mangrove, Onrizal et al. (2005) pada kawasan taman nasional, dan Setiawan et al. (2006) pada kawasan hutan kota.

Salah satu kawasan hutan yang masih terjaga keberadaannya adalah Hutan Lindung Sentajo yang berada di daerah Kabupaten Kuantan Singingi, Provinsi Riau. Minimnya informasi dan masih kurangnya penelitian yang menggambarkan potensi Hutan Lindung Sentajo menjadi daya tarik tersendiri untuk dilakukan penelitian di Hutan Lindung Sentajo. Penelitian ini secara umum bertujuan untuk mengukur dan menghitung keanekaragaman, struktur, dan komposisi vegetasi pada masing-masing komunitas di Hutan Lindung Sentajo.

\section{METODE PENELITIAN}

\section{Tempat dan Waktu Penelitian}

Penelitian ini dilaksanakan di Hutan Lindung Sentajo yang berada di Kecamatan Sentajo Raya, Kabupaten Kuantan Singingi, Provinsi Riau. Penelitian dilakukan pada bulan April - September 2016. Identifikasi herbarium dilakukan di Laboratorium Herbarium, Pusat Penelitian dan Pengembangan Hutan, Gunung Batu, Bogor. 


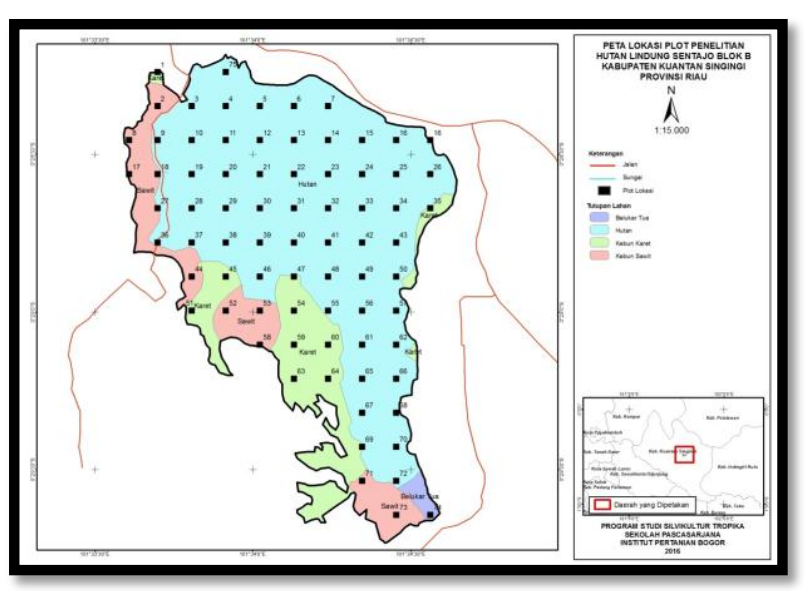

Gambar 1 Plot pengamatan di Hutan Lindung Sentajo blok B.

\section{Alat dan Bahan}

Alat dan bahan yang dibutuhkan dalam penelitian ini yaitu : peta kerja, GPS (Global Positioning System), kompas, alat tulis, tally sheet, meteran jahit, tongkat kayu $1.3 \mathrm{~m}$, tali rafia, label pohon, paku terali, palu, amplop, gunting, kantong plastik. Pengelolaan dan analisis data menggunakan seperangkat komputer yang dilengkapi perangkat Microsoft Office Excel 2009 sebagai tabulasi dan analisis data, SPSS 16.0 untuk cluster analysis dan ArcGIS 10.4.1 untuk pemetaan. Bahan penelitian adalah seluruh pohon dan permudaannya, serta habitus lainnya yang terdapat pada plot pengamatan dan peta Hutan Lindung Sentajo.

\section{Pelaksanaan Penelitian}

\section{Penentuan Desain Sampling dan Plot Penelitian}

Hutan Lindung Sentajo terdiri dari dua blok, yaitu blok A dan B. Penelitian ini dilakukan pada blok B, karena berdasarkan peta jenis tanah, tutupan lahan, elevasi, dan kemiringan, blok B lebih kompleks dan dapat mewakili ekosistem Hutan Lindung Sentajo.

Sistem sampling menggunakan teknik sistematik sampling dengan awal random (Systematic Sampling with Random Start). Peletakan atau pemilihan jalur ukur pertama dilakukan secara acak (random) dan jalur berikutnya diletakkan secara sistematik. Intensitas sampling yang digunakan yaitu 5\% dengan jarak antar plot $200 \mathrm{~m}$ (Gambar 1). Metode pengambilan contoh untuk analisis komunitas tumbuhan adalah metode petak ganda, dengan jumlah plot sebanyak 75 plot (ukuran 20 $\mathrm{m} \times 100 \mathrm{~m}$ ) atau seluas \pm 15 ha pengamatan.

Arah plot memanjang dari utara ke selatan. Hal ini dikarenakan adanya pengaruh cahaya matahari yang akan mempengaruhi jenis-jenis vegetasi, sehingga dengan peletakan arah plot yang memanjang dari utara ke selatan akan lebih mewakili komposisi dan struktur jenis vegetasi di Hutan Lindung Sentajo.

\section{Identifikasi Jenis Pohon dan Pembuatan Herbarium}

Pohon-pohon yang terdapat di dalam plot diidentifikasi oleh masyarakat lokal, sedangkan untuk pohon yang tidak dikenali akan dibuat herbarium. Herbarium yang telah dibuat dicocokkan dengan koleksi herbarium di Laboratorium Herbarium, Pusat Penelitian dan Pengembangan Hutan, Gunung Batu, Bogor.

\section{Analisis Data}

\section{Pembagian Komunitas Hutan}

Pembagian komunitas berdasarkan jenis tanah, kelerengan, dan elevasi. Peta tanah berasal dari Balai Besar Penelitian dan Pengembangan Sumberdaya Lahan Pertanian (BBDSLP), Cimanggu, Bogor dan peta kawasan Hutan Lindung Sentajo berasal dari Badan Pemantapan Kawasan Hutan (BPKH) wilayah XIX Riau di Pekanbaru yang didalamnya terdapat data kelerengan dan elevasi. Peta tanah, kelerengan, dan elevasi Hutan Lindung Sentajo dioverlay menggunakan Arcgis. Overlay merupakan penggabungan peta yang berfungsi untuk mencari peta analisis. Hasil overlay dikelompokkan, sehingga didapatkan komunitaskomunitas yang lebih seragam.

\section{Indeks Nilai Penting (INP)}

Indeks nilai penting merupakan hasil penjumlahan $\mathrm{Kr}$ (kerapatan relatif) + Fr (frekuensi relatif) + Dr (dominansi relatif). Hasil penjumlahan akan didapatkan INP yang akan dianalisis untuk menduga keanekaragaman jenis pohon di Hutan Lindung Sentajo.

\section{Kesamaan Komunitas}

Besar kecilnya indeks kesamaan atau Indeks of Similarity (IS) menggambarkan tingkat kesamaan komposisi spesies dan stuktur dari dua komunitas tegakan atau unit sampling yang dibandingkan (Indriyanto 2006). Indeks kesamaan dapat dihitung dengan menggunakan rumus sebagai berikut (Soerianegara \& Indrawan 1982) :

Ket :

$$
I S=\frac{2 W}{a+b} \times 100 \%
$$

IS = indeks kesamaan,

$\mathrm{W}=$ jumlah dari nilai penting yang lebih kecil atau sama dari dua spesies berpasangan, yang ditemukan pada dua komunitas,

$\mathrm{b}=$ total nilai penting dari komunitas $\mathrm{A}$,

$\mathrm{a}=$ total nilai penting dari komunitas $\mathrm{B}$.

Nilai indeks kesamaan berkisar antara $0-100$. Djufri (2006) membagi nilai indeks kesamaan menjadi empat bagian yaitu jika kemiripan sangat tinggi apabila IS $>75 \%$, kemiripan tinggi apabila IS > 50 - 75\%, kemiripan rendah apabila IS > $25-50 \%$, kemiripan sangat rendah apabila IS $<25 \%$. Membandingkan tingkat kedekatan antar komunitas maka dilanjutkan dengan cluster analysis.

\section{Indeks Keanekaragaman Jenis}

Keanekaragaman spesies yang tinggi menunjukkan bahwa suatu komunitas memiliki kompleksitas tinggi karena interaksi spesies yang terjadi dalam komunitas itu sangat tinggi. Menghitung keanekaragaman spesies dengan menggunakan keanekaragaman jenis ShannonWienner (Odum 1996) sebagai berikut : 


$$
H^{\prime}=-\sum_{i=1}^{s} p i \ln p i ; p i=\frac{n i}{N}
$$

Ket:

H' = menyatakan indeks keanekaragaman ShannonWienner,

ni $=$ jumlah individu setiap spesies,

$\mathrm{N}=$ jumlah individu semua jenis.

Indeks keanekaragaman Shannon-Wienner (H') dibagi menjadi empat kategori (Kusumo et al. 2016) diantaranya : $\mathrm{H}^{\prime}=1-2$ dikategorikan rendah, $\mathrm{H}^{\prime}=2-$ 3 dikategorikan sedang, $\mathrm{H}^{\prime}=3-4$ dikategorikan tinggi, $\mathrm{H}^{\prime}=>4$ dikategorikan sangat tinggi.

\section{Indeks Kemerataan Jenis}

Indeks kemerataan jenis (E) menunjukkan tingkat kemerataan individu per jenis. Indeks kemerataan/ Evenness Index (Odum 1996) dengan rumus sebagai berikut :

Ket:

$$
E=\frac{H^{\prime}}{\ln (s)}
$$

$\mathrm{E}=$ indeks kemerataan jenis,

$\mathrm{H}^{\prime}$ = indeks keanekaragaman Shannon-Wienner,

$\ln =$ logaritma natural,

$\mathrm{s} \quad=$ jumlah individu semua jenis

Nilai indeks kemerataan berkisar antara 0 sampai 1. Nilai indeks mendekati 0 maka kemerataan spesies rendah, sebaliknya jika mendekati 1 maka kemerataan tinggi (Bando et al. 2016).

\section{Indeks Dominansi}

Indeks dominansi (index of dominance) adalah parameter yang menyatakan tingkat terpusatnya dominansi (penguasaan) spesies dalam suatu komunitas. Menghitung indeks dominansi (ID) dengan rumusan sebagai berikut (Indriyanto 2006) :

Ket :

$$
\mathrm{ID}=\sum_{\mathrm{i}=1}^{\mathrm{n}}(n . i / N)^{2}
$$

ID = indeks dominansi,

n.i = nilai penting tiap spesies ke-i,

$\mathrm{N} \quad=$ total nilai penting.

Nilai indeks dominansi jenis berkisar antara $0 \leq$ ID $\leq$ 1. Apabila suatu tegakan hanya dikuasai oleh satu jenis saja maka nilai ID akan mendekati 1, dengan kata lain telah terjadi pengelompokan/ pemusatan suatu jenis tumbuhan. Apabila nilai ID mendekati nilai 0, maka tidak terjadi pemusatan suatu jenis karena terdapat beberapa jenis mendominasi secara bersama-sama (Ghufrona et al. 2015).

\section{HASIL DAN PEMBAHASAN}

\section{Jumlah Vegetasi Penyusun Hutan Lindung Sentajo}

Kekayaan spesies adalah jumlah spesies dalam suatu komunitas. Mengetahui kekayaan spesies merupakan hal mendasar untuk berbagai bidang dalam ekologi komunitas (Colwell \& Coddington 1994), sehingga untuk keperluan analisis lanjutan perlu diketahui jenisjenis vegetasi pada hutan tersebut. Hasil penelitian menunjukkan bahwa Hutan Lindung Sentajo memiliki 424 jenis flora termasuk dalam 254 genus dan 102 famili (Tabel 1). Hasil penelitian menunjukkan bahwa $80 \%$ tumbuhan penyusun Hutan Lindung Sentajo merupakan tumbuhan berkambium (berkayu). Keanekaragaman vegetasi Hutan Lindung Sentajo lebih tinggi apabila dibandingkan dengan Taman Nasional Tesso Nilo (TNTN) dan Taman Nasional Batang Gadis (TNBG).

Tabel 1 Jumlah vegetasi penyusun Hutan Lindung Sentajo

\begin{tabular}{clccc}
\hline No & Jenis Tumbuhan & Spesies & Genus & Famili \\
\hline 1 & Berkambium & 338 & 184 & 67 \\
2 & Tidak Berkambium & 86 & 70 & 35 \\
& Total & 424 & 254 & 102 \\
\hline
\end{tabular}

Hasil penelitian Lembaga Independent Peneliti Indonesia (LIPI) menunjukkan bahwa TNTN memiliki 360 jenis flora termasuk dalam 165 genus dan 57 famili (Yulianto 2014), sedangkan hasil penelitian Kartawinata et al. (2004) di TNBG teridentifikasi sekitar 240 jenis yang terdiri dari 47 famili atau sekitar $0.9 \%$ dari Flora yang ada di Indonesia. Tingginya keanekaragaman vegetasi di Hutan Lindung Sentajo karena hutan ini merupakan salah satu hutan hujan tropis dataran rendah yang terkenal akan kekayaan keanekaragaman hayati.

\section{Pembagian Komunitas Hutan}

Berdasarkan hasil interpretasi citra satelit Spot 6 dan pengamatan langsung (ground chek) kawasan Hutan Lindung Sentajo memiliki 4 kelas tutupan lahan (Tabel 2) diantaranya hutan, belukar tua, kebun karet, dan kebun sawit.

Tabel 2 Hasil pengukuran tutupan lahan di Hutan Lindung Sentajo

\begin{tabular}{clcc}
\hline No. & Tutupan Lahan & Luas (ha) & Luas (\%) \\
\hline 1 & Hutan & 216.40 & 71.15 \\
2 & Belukar Tua & 2.98 & 0.97 \\
3 & Kebun Karet & 37.17 & 12.05 \\
4 & Kebun Sawit & 48.83 & 15.83 \\
& Total & 305.38 & 100.00 \\
\hline
\end{tabular}

Kawasan dengan tutupan rapat (hutan) dibagi dan dikelompokkan berdasarkan jenis tanah, elevasi, dan kelerengan (Tabel 3). Pembagian komunitas ketiga komponen tersebut berpengaruh terhadap komposisi jenis vegetasi. Hal ini diperkuat dengan pernyataan Kalima (2008) yang menyatakan bahwa faktor pembatas untuk pertumbuhan dan persebaran tumbuhan yang paling menentukan adalah faktor iklim, tanah, dan ketinggian tempat. Hasil pembagian tutupan hutan terdapat 6 komunitas (Gambar 2). 


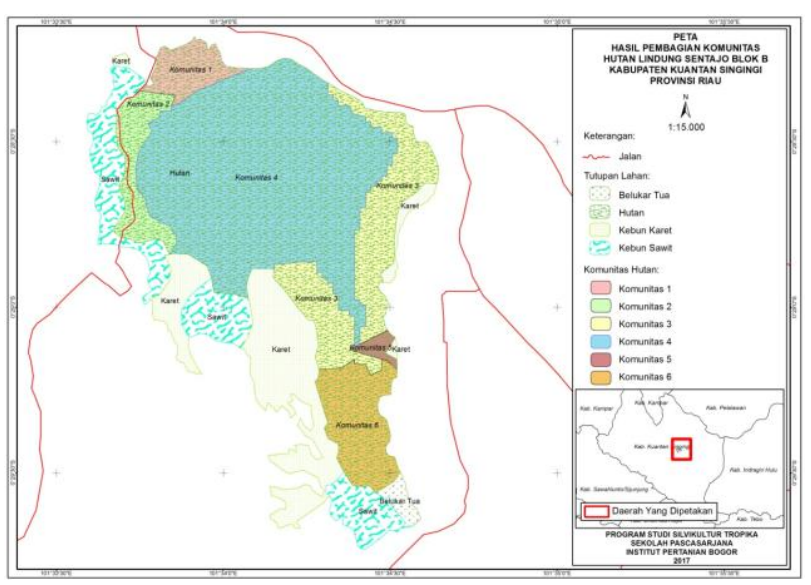

Gambar 2 Hasil pembagian komunitas Hutan Lindung Sentajo

Tabel 3 Pembagian komunitas berdasarkan kondisi fisik di Hutan Lindung Sentajo.

\begin{tabular}{|c|c|c|c|c|c|c|}
\hline No. & Komunitas & Jenis Tanah & Kelerengan (\%) & Elevasi (mdpl) & Luas (ha) & Luas (\%) \\
\hline 1 & $\mathrm{~K} 1$ & 1 & $0-3$ & $100-120$ & 16.41 & 7.58 \\
\hline 2 & K2 & 1 & $8-15$ & $80-100$ & 14.34 & 6.63 \\
\hline 3 & K3 & 1 & $8-15$ & $100-120$ & 28.11 & 12.99 \\
\hline 4 & K4 & 1 & $3-8$ & $100-120$ & 132.86 & 61.40 \\
\hline 5 & K5 & 3 & $0-3$ & $80-100$ & 2.26 & 1.04 \\
\hline 6 & K6 & 2 & $8-15$ & $60-80$ & 22.42 & 10.36 \\
\hline \multicolumn{5}{|c|}{ Jumlah } & 216.40 & 100.00 \\
\hline
\end{tabular}

Ket: 1. Dystropepts, Humitropepts, Tropohumods, Tropaquepts; 2 Dystropepts, Kaniudults; 3. Dystropepts, Humitropepts, Tropaquepts; K = Komunitas.

\section{Indeks Kesamaan}

Hasil perhitungan menunjukkan bahwa komunitas 3 dan 4 merupakan komunitas yang paling dekat dengan nilai 64. Indeks kesamaan yang paling jauh berada pada komunitas 5 dan 3 (Tabel 4).

Tabel 4 Perbandingan indeks kesamaan antar komunitas (K) di Hutan Lindung Sentajo.

\begin{tabular}{ccccccc}
\hline \multicolumn{7}{c}{ Indeks Kesamaan (IS) } \\
\hline & K1 & K2 & K3 & K4 & K5 & K6 \\
\hline K1 & & 43 & 45 & 57 & 25 & 44 \\
K2 & 57 & & 54 & 54 & 24 & 55 \\
K3 & 55 & 46 & & 64 & 18 & 61 \\
K4 & 43 & 46 & 36 & & 19 & 60 \\
K5 & 75 & 76 & 82 & 81 & & 18 \\
K6 & 56 & 45 & 39 & 40 & 82 & \\
\hline \multicolumn{7}{c}{ Indeks Ketidaksamaan (IK) } \\
\hline \multicolumn{7}{c}{}
\end{tabular}

Hasil analisis klaster (Gambar 3) menggunakan Euclidean Distances. Posisi masing-masing komunitas pada dendrogram menggambarkan perbedaan komposisi diantara komunitas. Komunitas yang posisinya berdekatan dan dihubungkan dengan garis penghubung, menunjukkan bahwa komunitas tersebut memiliki kemiripan yang tinggi dan sebaliknya. Pengelompokan komunitas yang paling berbeda adalah komunitas 5 . Komunitas yang memiliki kemiripan tinggi diantaranya komunitas 2, 3, 1, dan 4.
Komunitas

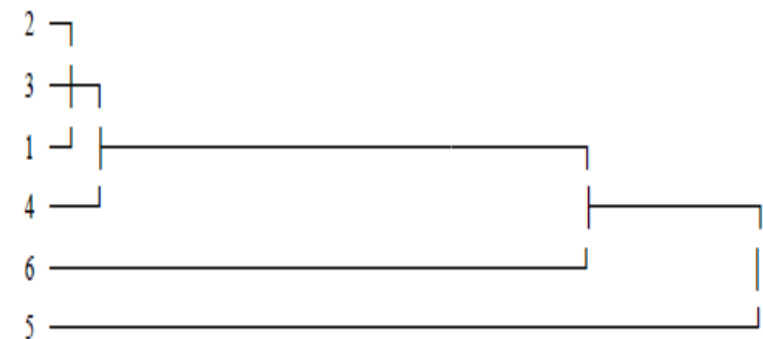

Gambar 3 Dendrogram hasil analisis klaster pada masing-masing komunitas

\section{Jenis Dominan pada Komunitas Hutan}

Spesies dengan Indeks Nilai Penting (INP) tertinggi menunjukkan nilai penguasaan spesies dalam suatu komunitas. Nilai penting suatu spesies dapat dijadikan indikasi bahwa spesies tersebut dianggap dominan dengan memiliki nilai kerapatan relatif, frekuensi relatif, dan dominansi relatif yang lebih tinggi dibandingkan dengan spesies lain (Setiadi 2004). Spesies yang memiliki INP sepuluh besar tertinggi pada masingmasing komunitas dapat dilihat pada Tabel 5.

Kempas (Koompassia malaccencis) merupakan jenis yang paling dominan pada komunitas 1 dan 4. Jenis tumbuhan ini banyak ditemukan pada kedua lokasi tersebut. Komunitas 2 dan 6 sama-sama didominasi oleh Medang (Litsea castanea), sedangkan komunitas 3 didominasi oleh jenis pohon Medang (Litsea odorifera) (Tabel 5). Besarnya indeks nilai penting menunjukkan peranan jenis yang bersangkutan dalam komunitasnya atau pada lokasi penelitian. Kemampuan tumbuhan yang dominan menempati sebagian besar lokasi penelitian menunjukkan bahwa tumbuhan tersebut memiliki kemampuan adaptasi di seluruh lokasi penelitian (Arrijani et al. 2006).

\section{Struktur Hutan}

\section{Struktur Horizontal dan Sebaran Kelas Diameter}

Kerapatan tegakan merupakan besarnya populasi dalam suatu unit ruang yang pada umumnya dinyatakan sebagai jumlah individu dalam suatu unit ruang tertentu. Hasil analisis memperlihatkan bahwa struktur populasi setiap spesies tumbuhan berbentuk $\mathbf{J}$ terbalik (spesies anakan lebih banyak dari pada tingkatan spesies lainnya).

Gambar 4 menunjukkan bahwa sebaran kelas diameter dan kerapatan pohon pada Hutan Lindung Sentajo termasuk tipe hutan normal, hal ini diperkuat dengan hasil penelitian Bismark et al. (2008) yang menyatakan bahwa semakin besar kelas diameter pohon maka populasi pohon (N/ha) akan semakin sedikit. Rendahnya tingkat kerapatan pohon yang berdiameter > $60 \mathrm{~cm}$ jika dibandingkan dengan kerapatan pohon yang memiliki kelas diameter dibawahnya disebabkan adanya kompetisi tumbuhan dalam memperebutkan ruang tumbuh, cahaya, dan unsur hara. 
Tabel 5 INP pada masing-masing komunitas di Hutan Lindung Sentajo

\begin{tabular}{|c|c|c|c|c|c|c|c|c|}
\hline No & Nama Ilmiah & INP & No & Nama Ilmiah & INP & No & Nama Ilmiah & INP \\
\hline & Komunitas 1 & & & Komunitas 2 & & & Komunitas 3 & \\
\hline 1 & $\begin{array}{l}\text { Koompassia } \\
\text { malaccensis }\end{array}$ & 38.21 & 1 & Litsea castanea & 22.07 & 1 & Litsea odorifera & 20.73 \\
\hline 2 & Litsea odorifera & 16.54 & 2 & $\begin{array}{l}\text { Gironniera } \\
\text { subaequalis }\end{array}$ & 19.83 & 2 & Santiria leavigata & 16.58 \\
\hline 3 & $\begin{array}{l}\text { Calophyllum } \\
\text { pulcherrium }\end{array}$ & 13.01 & 3 & Palaquium burckii & 19.03 & 3 & $\begin{array}{l}\text { Ochanostachys } \\
\text { amentaceae }\end{array}$ & 14.90 \\
\hline 4 & Shorea parvipolia & 12.99 & 4 & Litsea robusta & 18.92 & 4 & Ixonanthes icosandra & 13.34 \\
\hline 5 & Polyalthia rumphii & 12.11 & 5 & Paratocarpus triandus & 16.94 & 5 & $\begin{array}{l}\text { Diallium } \\
\text { platysephallum }\end{array}$ & 12.61 \\
\hline 6 & Palaquium burckii & 11.79 & 6 & $\begin{array}{l}\text { Endospermum } \\
\text { diadenum }\end{array}$ & 12.11 & 6 & $\begin{array}{l}\text { Paratocarpus } \\
\text { triandus }\end{array}$ & 11.41 \\
\hline 7 & $\begin{array}{l}\text { Cratoxylum } \\
\text { formasum }\end{array}$ & 11.67 & 7 & Shorea teysmanniana & 10.93 & 7 & $\begin{array}{l}\text { Endospermum } \\
\text { diadenum }\end{array}$ & 9.49 \\
\hline 8 & $\begin{array}{l}\text { Paratocarpus } \\
\text { triandus }\end{array}$ & 8.31 & 8 & Syzygium subglauca & 10.69 & 8 & Litsea robusta & 8.68 \\
\hline 9 & $\begin{array}{l}\text { Syzygium } \\
\text { densiflorum }\end{array}$ & 7.53 & 9 & Litsea odorifera & 10.18 & 9 & Syzygium densiflora & 8.28 \\
\hline 10 & $\begin{array}{l}\text { Diallium } \\
\text { platysephallum } \\
\quad \text { Komunitas } 4\end{array}$ & 7.48 & 10 & $\begin{array}{l}\text { Ochanostachys } \\
\text { amentaceae } \\
\quad \text { Komunitas } 5\end{array}$ & 9.89 & 10 & $\begin{array}{r}\text { Palaquium burckii } \\
\text { Komunitas } 6\end{array}$ & 8.13 \\
\hline 1 & $\begin{array}{l}\text { Koompassia } \\
\text { malaccensis }\end{array}$ & 34.47 & 1 & Gironniera nervosa & 35.99 & 1 & Litsea castanea & 24.39 \\
\hline 2 & Santiria leavigata & 22.76 & 2 & Shorea brachteolata & 31.23 & 2 & Litsea odorifera & 22.76 \\
\hline 3 & Litsea odorifera & 18.79 & 3 & Syzygium antisepticum & 30.60 & 3 & Artocarpus integra & 16.76 \\
\hline 4 & Palaquium burckii & 17.67 & 4 & Syzygium corinanthum & 24.53 & 4 & Santiria leavigata & 14.25 \\
\hline 5 & Shorea parvipolia & 16.03 & 5 & Irvingia malayana & 24.02 & 5 & Shorea brachteolata & 11.99 \\
\hline 6 & $\begin{array}{l}\text { Diallium } \\
\text { platysephallum }\end{array}$ & 10.51 & 6 & Bhesa paniculata & 23.44 & 6 & Dacryodes rostata & 10.98 \\
\hline 7 & Litsea robusta & 9.35 & 7 & Chucrasia tabularis & 22.15 & 7 & Shorea conica & 10.87 \\
\hline 8 & $\begin{array}{l}\text { Ochanostachys } \\
\text { amentaceae }\end{array}$ & 9.14 & 8 & Palaquium burckii & 16.03 & 8 & Shorea parvipolia & 10.51 \\
\hline 9 & $\begin{array}{l}\text { Dactylocladus } \\
\text { stenostachys }\end{array}$ & 9.03 & 9 & Litsea robusta & 14.66 & 9 & $\begin{array}{l}\text { Ochanostachys } \\
\text { amentaceae }\end{array}$ & 10.23 \\
\hline 10 & Shorea brachteolata & 8.24 & 10 & Dyospiros macrophylla & 13.17 & 10 & $\begin{array}{l}\text { Koompassia } \\
\text { malaccensis }\end{array}$ & 10.13 \\
\hline
\end{tabular}

K1

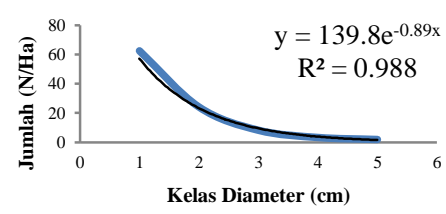

K4

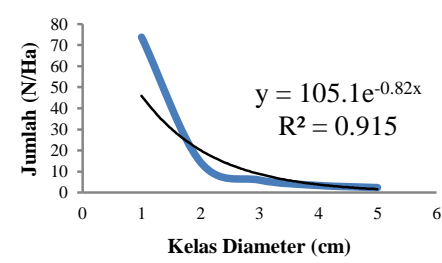

K2

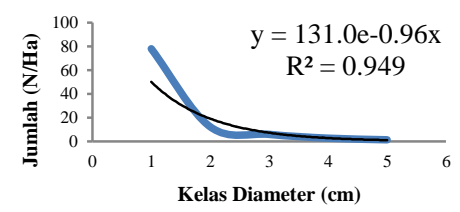

K5

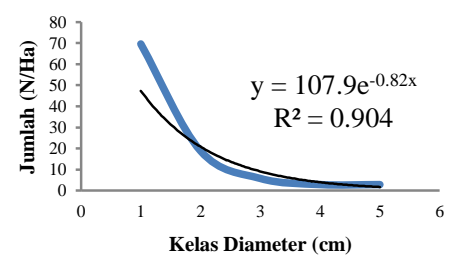

K3

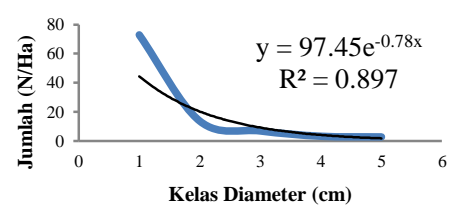

K6

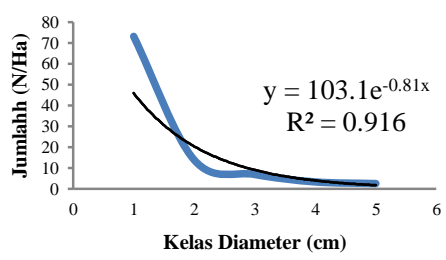

Gambar 4 Struktur horizontal dan sebaran kelas diameter di Hutan Lindung Sentajo. Keterangan; K (komunitas), y (persamaan), $\mathrm{R}^{2}$ (tingkat kepercayaan), e (eksponensial), KD (Kelas Diameter) 1: $10 \mathrm{~cm} \leq \mathrm{KD}<20 \mathrm{~cm}$; 2: $20 \mathrm{~cm} \leq \mathrm{KD}<40 \mathrm{~cm} ; 3: 40 \mathrm{~cm} \leq \mathrm{KD}<50 \mathrm{~cm}$; $5: 50 \mathrm{~cm} \leq \mathrm{KD}<60 \mathrm{~cm}$. 
Tabel 6 Jenis vegetasi pohon dominan yang membentuk stratifikasi tajuk di Hutan Lindung Sentajo

\begin{tabular}{|c|c|c|}
\hline No & Tingkat Strata & Jenis Vegetasi \\
\hline 1 & $\mathrm{~A}(>30 \mathrm{~m})$ & $\begin{array}{l}\left.\text { Kempas (Koompassia malaccensis) })^{1234} \text {, Meranti Sabut (Shorea brachteolata }\right)^{1234} \text {, } \\
\text { Meranti Batu (Parashorea aptera })^{34} \text {, Meranti Bunga (Shorea parvipolia) }{ }^{1234} \text {, Rengas } \\
\text { (Melanorhoea walichii) }^{6}\end{array}$ \\
\hline 2 & B (20 - $30 \mathrm{~m})$ & $\begin{array}{l}\text { Balam Merah (Palaquium burckii) })^{123456} \text {, Meranti Sabut }(\text { Shorea brachteolata })^{123456} \text {, } \\
\text { Kempas }(\text { Koompassia malaccensis })^{12346} \text {, Meranti Batu }(\text { Parashorea aptera })^{34}, \text { Keranji } \\
(\text { Diallium platysephallum })^{12346} \text {, Bintangur Jangkar }(\text { Calophyllum pulcherrium })^{1234} \text {. }\end{array}$ \\
\hline 3 & $\mathrm{C}(4-20 \mathrm{~m})$ & $\begin{array}{l}\left.\text { Kelat }(\text { Syzygium sp. })^{123456} \text {, Meranti (Shorea sp. }\right)^{123456} \text {, Rambutan Hutan (Nephelium } \\
\left.\text { lapaceum })^{1234} \text {, Kulim (Scorodocarpus borneensis }\right)^{12346} \text {, Mempening (Lithocarpus } \\
\left.\text { eichleri Werz) })^{12346} \text {, Pagar-Pagar (Ixonanthes icosandra) }\right)^{12346} \text {, Tempinis (Sloetia } \\
\left.\text { elongata })^{123456} \text {, Tampui (Baccaurea deflexa) }\right)^{12346} \text {. }\end{array}$ \\
\hline 4 & $\mathrm{D}(1-4 \mathrm{~m})$ & $\begin{array}{l}\left.\text { Anakan Meranti }(\text { Shorea sp. })^{123456} \text {, Ribu-Ribu (Diospyros buxifolia }\right)^{123456} \text {, Nasi-Nasi } \\
(\text { Syzygium buxifolium })^{16} \text {, Kelat }(\text { Syzygium sp. })^{123456}\end{array}$ \\
\hline 5 & $\mathrm{E}(<1 \mathrm{~m})$ & $\operatorname{Rotan}^{146}$, Pandan $^{146}$, Paku-Pakuan ${ }^{123456}$ \\
\hline
\end{tabular}

Keterangan : 123456 (Komunitas ke)

\section{Struktur Vertikal dan Analisis Permudaan}

Berdasarkan Gambar 5 terlihat bahwa semua lokasi pengamatan di Hutan Lindung Sentajo membentuk $L$ form (Life form/bentuk pertumbuhan). Ghufrona et al. (2015) menyatakan bahwa kondisi hutan yang membentuk $L$-form menunjukkan populasi pohon pada lokasi tersebut berkembang kearah uneven-age balanced forest (hutan segala umur yang seimbang) yaitu semakin besar ukuran diameter pohon semakin sedikit jumlah individunya. Selain membentuk $L$-form, Shankar (2001) mengelompokkan kriteria regenerasi menjadi lima bagian yaitu good, fair, poor, none, dan new. Hutan Lindung Sentajo tergolong good, artinya semai > pancang > pohon dewasa (Gambar 4).

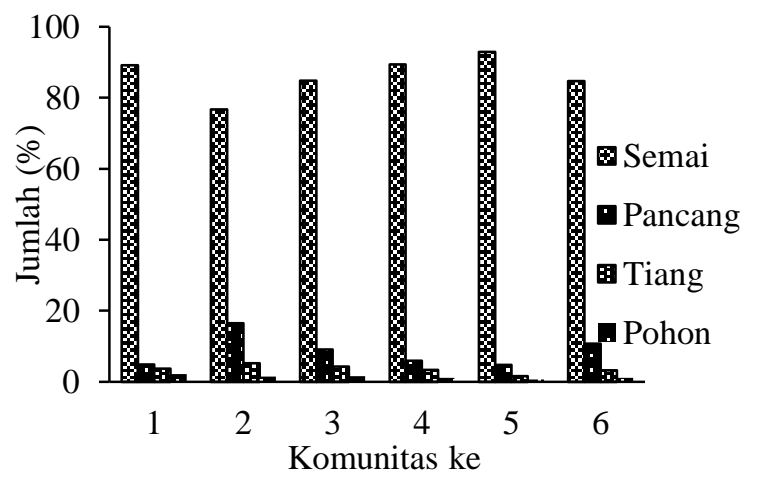

Gambar 5 Jumlah permudaan di Hutan Lindung Sentajo

Hutan Lindung Sentajo merupakan hutan alam yang ditumbuhi dan disusun oleh pohon-pohon secara alami. Tabel 6 menunjukkan bahwa Meranti ditemukan pada setiap strata, sedangkan Kempas hanya ditemukan pada strata C dan D. Hardiwinoto et al. (2005) menyatakan bahwa apabila dalam jangka yang lama tidak ada pembukaan naungan maka anakan pohon akan mati, semai baru akan tumbuh kembali pada musim buah berikutnya. Apabila terjadi pembentukan celah (gap) maka semai tersebut akan tumbuh yang cepat. Secara umum sifat dari Meranti mampu bertahan hidup dalam jangka waktu yang cukup lama di bawah naungan, kemudian tumbuh dengan cepat pada saat terjadi bukaan tajuk, sehingga Meranti ditemukan pada setiap strata dan menjadi emergent tree di Hutan Lindung Sentajo.
Anakan Kempas diduga tidak mampu bersaing, sehingga sulit ditemukan pada strata C dan D.

\section{Komposisi Hutan}

\section{Indeks Keanekaragaman, Kemerataan, dan Dominansi Jenis}

Suatu komunitas dikatakan memiliki keanekaragaman spesies yang tinggi jika komunitas itu disusun oleh banyak spesies. Berdasarkan perhitungan indeks keanekaragaman Shannon-Wiener menunjukkan bahwa Hutan Lindung Sentajo memiliki indeks keanekaragaman yang sedang, tinggi, hingga sangat tinggi. Keaneka-ragaman tertinggi terdapat pada komunitas 3 dan 4 dengan nilai 4.15 , sedangkan terendah pada komunitas 5 .

Tabel 7 Indeks keanekaragaman, kemerataan, dan dominansi jenis

\begin{tabular}{ccccccc}
\hline & $\mathrm{K} 1$ & $\mathrm{~K} 2$ & $\mathrm{~K} 3$ & $\mathrm{~K} 4$ & $\mathrm{~K} 5$ & $\mathrm{~K} 6$ \\
\hline $\mathrm{H}^{\prime}$ & 3.78 & 3.68 & 4.15 & 4.15 & 2.62 & 3.78 \\
$\mathrm{E}$ & 0.78 & 0.68 & 0.70 & 0.59 & 0.86 & 0.70 \\
$\mathrm{ID}$ & 0.03 & 0.03 & 0.02 & 0.03 & 0.08 & 0.03 \\
\hline
\end{tabular}

Ket : $\mathrm{K}=$ Komunitas, $\mathrm{H}^{\prime}=$ Indeks keanekaragaman jenis, $\mathrm{E}=$ Indeks kemerataan, ID = Indeks dominansi

Indeks kemerataan jenis menunjukkan tingkat kemerataan individu pada tiap jenis di lokasi penelitian. Semakin tinggi nilai indeks kemerataan maka semakin merata spesies tersebut tersebar di lokasi penelitian. Tingkat kemerataan jenis tertinggi terdapat pada komunitas 5 dan terendah pada komunitas 4 (Tabel 7). Hal ini diperkirakan karena pada komunitas merupakan komunitas yang memiliki keanekaragaman tertinggi, sedangkan komunitas 5 merupakan daerah yang keanekaragamannya rendah.

Indeks dominansi jenis bertujuan untuk mengetahui pemusatan atau penguasaan suatu jenis pada suatu lokasi. Berdasarkan hasil perhitungan (Tabel 7), nilai indeks dominansi mendekati 0 , maka tidak terjadi pemusatan jenis pada masing-masing komunitas di Hutan Lindung Sentajo. Artinya pada lokasi penelitian tidak ada jenis yang sangat mendominasi. 


\section{SIMPULAN}

Terdapat enam tipe komunitas di Hutan Lindung Sentajo. Keanekaragaman vegetasi di Hutan Lindung Sentajo tergolong tinggi. Hasil penelitian menunjukkan bahwa Hutan Lindung Sentajo memiliki 424 jenis Flora termasuk dalam 254 genus dan 102 famili. Hutan Lindung Sentajo memiliki indeks kesamaan antara 18 $64 \%$, indeks keanekaragaman jenis $2.62-4.15$, indeks kemerataan $0.59-0.86$, indeks dominansi $0.02-0.08$. Semakin besar ukuran diameter pohon semakin sedikit jumlah individunya dan stratifikasi tajuk memiliki 5 lapisan tajuk. Permudaan di Hutan Lindung Sentajo tergolong baik dimana jumlah semai > pancang $>$ pohon dewasa.

\section{DAFTAR PUSTAKA}

Arrijani, Setiadi D, Guhardja E, Qayim I. 2006. Analisis vegetasi hulu DAS Cianjur Taman Nasional Gunung Gede-Pangrango. Biodiversitas 7(2):147153.

Bando AH, Siahaan R, Langoy MLD. 2016. Keanekaragaman vegetasi riparian di Sungai Tewalen, Minahasa Selatan, Sulawesi Utara. Jurnal Ilmu Sains 16(1):7-11.

Bismark M, Heriyanto NM, Sofian I. 2008. Biomassa dan kandungan karbon pada hutan produksi di Cagar Biosfer Pulau Siberut, Sumatera Barat. Jurnal Penelitan Hutan dan Konservasi Alam. 5(5).:397-407.

Colwell RK, Coddington JA. 1994. Estimating terrestrial biodiversity through extrapolation. Philosophical Transaction: Biological Science 345(1311):101-118.

Djufri. 2006. Studi Autekologi dan pengaruh invasi Akasia (Acacia nilotica) (L.) Willd.Ex.Del terhadap eksistensi savana dan strategi penanganannya di Taman Nasional Baluran, Banyuwangi, Jawa Timur. [Disertasi]. Sekolah Pascasarjana, Institut Pertanian Bogor.

Ghufrona RR, Kusmana C, Rusdiana O. 2015. Komposisis jenis dan struktur Hutan Mangrove di Pulau Sebuku, Kalimantan Selatan. Jurnal Silvikultur Tropika 6(1):15-26.

Hardiwinoto S, Priyanto SDA, Adriana, Widyatno. 2005. Silvikultur. Fakultas Kehutanan Universitas Gadjah Mada. Yogyakarta (ID).
Indriyanto. 2012. Ekologi Hutan. Jakarta (ID): Bumi Aksara.

Junaedi DI. 2008. Keragaman komunitas tumbuhan di Taman Nasional Gunung Ciremai. Buletin Kebun Raya Indonesia 11(2):25-32.

Kalima T. 2008. Profil keragaman dan keberadaan spesies dari suku Dipterocarpaceae di Taman Nasional Meru Betiri, Jember. Jurnal Penelitian Hutan dan Konservasi Alam 5(2):175-191.

Kartawinata K, Samsoedin I, Heriyanto M, Afriastini JJ. 2004. A tree species inventory in a one hectare plot at the Batang Gadis National Park, North Sumatra, Indonesia. Reinwardtia 12(2):145-157.

Kusumo A, Bambang AN, Izzati M. 2016. Struktur vegetasi kawasan hutan alam dan hutan rerdegradasi di Taman Nasional Tesso Nilo. Jurnal Ilmu Lingkungan 14(1):19-26.

Mukhlisin, Hendrarto BI, Purnaweni H. 2013. Keanekaragaman jenis dan struktur vegetasi mangrove di desa Sidodadi kecamatan Padang Cermin Kabupaten Pesawaran, Provinsi Lampung. Prosiding Seminar Nasional Pengelolaan Sumberdaya Alam dan Lingkungan. 218 -225.

Odum EP. 1996. Dasar-Dasar Ekologi. Edisi ke 3. Terjemahan Tjahjono Samingan. Yogyakarta (ID): Gadjah Mada University Press.

Onrizal, Kusmana C, Saharjo BH, Handayani IP, Kato T. 2005. Analisis vegetasi hutan hujan tropika dataran rendah sekunder di Taman Nasional Danau Sentarum, Kalimantan Barat. Jurnal Biologi 4(6):359-372.

Setiadi D. 2004. Keanekaragaman spesies tingkat pohon di Taman Nasional Alam Ruteng, Nusa Tenggara Timur. Biodiversitas 6:118-122.

Setiawan A, Alikodra HS, Gunawan A, Darnaedi D. 2006. Keanekaragaman jenis pohon dan burung di beberapa areal hutan kota Bandar Lampung. Jurnal Manajemen Hutan11(1):1-13.

Shankar U. 2001. A case of tree diversity in a sal (Shorea robusta) dominated lowland forest of eastern Himalaya: floristic composition, regeneration, and conservation. Current Science 81(7):776-786.

Soerianegara I, Indrawan A. 1982. Ekologi Hutan Indonesia. Bogor (ID): IPB.

Yulianto K. 2014. Panduan Lapangan pengenalan 101 jenis pohon hutan hujan dataran rendah. Taman Nasional Tesso Nilo. 